\title{
Clad \\ Congresso internacional debate novos desafios da administração pública
}

Cerca de duas mil pessoas, entre ministros, secretários de Estado, pesquisadores, parlamentares, técnicos e especialistas de 23 países, participaram do XIV Congresso Internacional sobre a Reforma do Estado e a Administração Pública, realizado em Salvador (BA), de 27 a 30 de outubro. Organizado pelo Centro Latino-americano de Admi-nistração para o Desenvolvimento (Clad), em parceria com o Ministério do Planejamento, Orçamento e Gestão, o encontro explorou sete áreas temáticas, apresentando análises teóricas, estudos de casos, desenvolvimento de técnicas e ferramentas inovadoras para o serviço público, em particular de países ibero-americanos.

Ao todo, foram realizados 130 painéis, com a apresentação de mais de 500 trabalhos, além de três conferências plenárias. Pela primeira vez, reservou-se espaço também para apresentação de pôsteres sobre pesquisas relacionadas ao tema do evento.

Nos quatro dias de congresso, o enfoque das discussões esteve baseado em sete áreas temáticas, coordenadas por representantes da Argentina, do Brasil, da Espanha e do México:

1) "Capacidades para governar o futuro através do processo de formação de políticas públicas", coordenada por Manuel Villoria Mendieta, diretor do
Departamento de Governo, Administração e Políticas Públicas do Instituto Universitário de Investigação Ortega y Gasset/Espanha;

2) "Enfoque interdisciplinar e coordenação intersetorial na gestão de uma administração pública completa", coordenada por Luis Alberto dos Santos, subchefe da Subchefia de Análise e Acompanhamento de Políticas Governamentais da Casa Civil da Presidência da República/Brasil;

3) "Em busca da excelência na administração pública por meio da gestão da qualidade e da gestão de resultados para o desenvolvimento", coordenada por Javier González Gómez, titular da Unidade de Avaliação da Gestão e do Desempenho Governamental, Subsecretaria da Função Pública, Secretaria da Função Pública/México;

4) "Em direção ao mérito profissional e à flexibilidade da gestão dos sistemas de função pública/serviço civil”, coordenada por José Enrique Martín Arahuetes, diretor geral da Função Pública/Espanha;

5) "Uma formação de dirigentes e funcionários públicos que persiga o êxito da ação de governo", coordenada por Helena Kerr do Amaral, presidente da Escola Nacional de Administração Pública (ENAP)/Brasil; 
6) "Valores, normas e instrumentos da ética pública para garantir o bom governo na Ibero-américa", coordenada por Roberto de Figueiredo Caldas, membro da Comissão de Ética Pública da Presidência da República/Brasil;

7) "Governo eletrônico para a participação popular e gestão do desenvolvimento", coordenada por Elida Rodríguez Bizole, assesora da Subsecretaria de Tecnologias de Gestão da Secretaria da Gestão Pública/Argentina.

Esses coordenadores receberam a missão de, ao final do congresso, elaborar um documento com as reflexões mais significativas das apresentações e debates (Leia na página **** a síntese da área temática "Uma formação de dirigentes e funcionários públicos que persiga o êxito da ação de governo", coordenada pela presidente da ENAP, Helena Kerr do Amaral).

Para mais informações sobre o XIV Congresso Internacional do Clad, acesse http: / / www.clad.org/congreso-clad. Nesta página, estão disponíveis para download as sínteses das áreas temáticas, os discursos das conferências, o detalhamento da programação, além de arquivos dos congressos anteriores.

\section{Conheça o Clad}

O Centro Latino-Americano de Administração para o Desenvolvimento é um organismo público internacional. Foi constituído em 1972 por iniciativa dos governos do México, Peru e Venezuela.

Sua criação foi recomendada pela Assembléia Geral das Nações Unidas (Resolução 2802 - XXVI), com o propósito de criar uma entidade regional que tem como raiz de suas atividades a modernização da administração pública, um fator estratégico no processo de desenvolvimento econômico e social.

A missão do Clad é promover a discussão e a troca de experiências e conhecimentos sobre a reforma do Estado e modernização da administração pública, organizando reuniões internacionais especializadas, publicando obras, prestando serviços de documentação e informação, realizando estudos e implementando a cooperação técnica entre seus países membros e de outras regiões.

Realizados anualmente, desde 1996, os congressos do Clad são considerados os mais importantes da América Latina para trocas de experiências e estudos sobre reforma do Estado e da administração pública. A cidade do Rio de Janeiro foi a sede da primeira edição. Nos anos seguintes, o congresso esteve presente em diversos países, como Espanha, Portugal, Argentina e Chile.

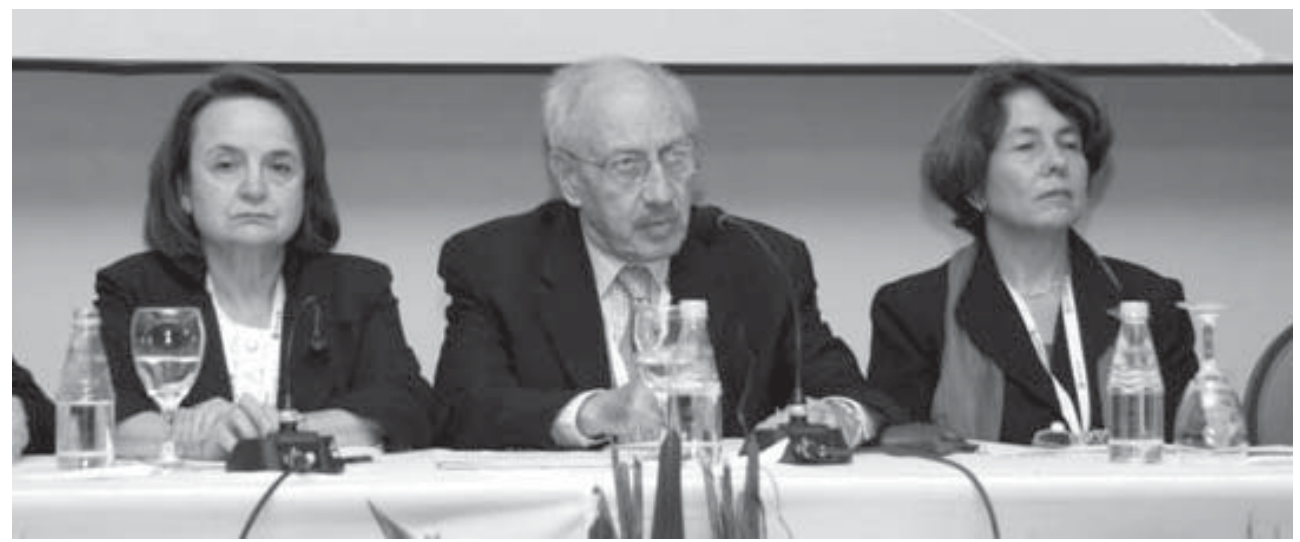

Elida Rodriguez, David Edelman e Helena Kerr na mesa de relatoria do XIV Clad 